\title{
BIOLOGICAL PROFILING OF CLAVICLE: A REVIEW
}

\author{
Bhavna Ahlawat \\ Department of Forensic Science \\ JGI Group, Bangalore, Karnataka, India
}

\begin{abstract}
Bones hold an important role in forensic anthropology investigation; long bones have always played the role of important evidence. Clavicle is a horizontal long bone and similarly holds great value in investigation of forensic crime scene investigation. The paper focuses on the role of clavicle in determination of biological profiling of an individual and what future measures should be taken towards it.
\end{abstract}

Keywords - Bones, Clavicle, Forensic Science, Crime scene investigation, Forensic Anthropology, Evidence.

\section{INTRODUCTION}

In the discipline of anthropology we seek to understand numerous intricate aspects of human beings. Anthropology is derived from the Greek word anthropos meaning "human" and logia meaning "study of", so anthropology seeks to study human behaviour, culture, language, development, biology, past, present and future. It is further divided into sub disciplines as social and physical anthropology. (TersigniTarrant \& Shirley, 2013). Forensic anthropology is a combination of physical anthropology and anatomy; together they make one specialisation helping the judicial system in investigation (Black, 2018). The field of forensic anthropology comprises of study of all aspects of recovery, concept formation, analysis, interpretation and investigation of human remains in all fronts (Dirkmaat, Garvin, \& Cabo, 2018).

After the determination of the anthropological evidences as human remains, next step is the sorting out the number of individuals present, which is referred as minimum number of individuals (MNI). For assessment various criterion are taken into consideration like orientation of bone, age, sex, fragmented parts, others (Langley \& Tersigni-Tarrant, 2017). The obtained skeletal remains can be further classifies into different categories depending on aspects of skeleton like based on location, size, shape, origin, and by structure (Burns, 2013). Based on location skeleton is divided into two categories, the axial skeleton and appendicular skeleton. Axial skeleton is base of foundation to appendicular skeleton comprises of skull, hyoid, backbone, sternum and ribs. The appendicular skeleton is attached with the axial skeleton on lateral sides and is always paired, includes pectoral girdle, arms, hands, pelvic girdle, legs and feet (Burns, 2013).

The aim of the study is to understand the biological profiling of clavicle as an evident bone during forensic investigation. The supporting structure for upper girdle is known as shoulder girdle which consists of clavicle and scapula as major bones. Connects the arm and trunk together (Christensen, Passalacqua, \& Bartelink, 2014). Clavicle is a tubular, S shaped bone, commonly called as collar bone lies horizontally and anteriorly across the thorax, superior in position to ribs (Tortora \& Derrickson, 2009) (Sarajlic \& Klonowski, 2012) (Schmitt, Cunha, \& Pinheiro, 2006). The bones looks S shaped because the medial $2 / 3^{\text {rd }}$ part is convex and lateral $1 / 3^{\text {rd }}$ part is concave (Singh, 2009).

In recent studies it has been significant that clavicle attribute to new paradigms in the field of anthropology and that includes the estimation of age, sex, race, stature and other relevant studies. The clavicle is among the first bone to ossify in-utero and last one to fuse and since hold a lot of significance in forensic anthropology. (T, Friedling, \& Gordon, 2018)

Most commonly the approached forensic anthropology uses includes macroscopic analysis, metric analysis and radiology, sometimes histology and elemental analysis is also included. Stature has become an important part of biological profiling of forensic anthropology study. There are basic two type of technique available for adult stature estimation that is mathematical and anatomical methods. The mathematical method uses regression formula where as anatomical methods involve measurements and addition of the lengths or heights of series of skeletal elements from cranium through foot and taking account of soft tissue components. Both these methods of stature estimation has not played same role while estimating the stature via clavicle measurements (Raxter \& Ruff, 2018). (Burns, 2013) (Auerbach, 2018).

With sex, age and race, stature plays an important role in identification of skeletal remains. Different bones has been used to estimate stature but error is still there with different criterions, as different factors are there which can affect the stature estimation including age and body changes as one of the biggest factors. (Torimitsu \& Makino, 2016). (Moore \& Ross, 2013) Some measurements that may prove useful in anthropometric study of clavicle are maximum length of 


\section{International Journal of Engineering Applied Sciences and Technology, 2020 \\ Vol. 5, Issue 4, ISSN No. 2455-2143, Pages 337-338 \\ Published Online August 2020 in IJEAST (http://www.ijeast.com)}

clavicle, sagittal diameter of clavicle, vertical diameter of clavicle (Tortora \& Derrickson, 2009). Different method includes regression method, fully method, and stature estimation from long bones length, Trotter and Gleser method, Giles method and many other similar. (Klepinger, 2006).

The auricular facet of clavicle undergoes characteristic changes from 18 to 30 year of age, similarly the medial end of clavicle undergo changes which can be a significant criterion for age estimation and it but no such difference has been noticed between left and right clavicle (Szilvássy, 1980) (Bhise, Chavan, \& Chikhalkar, 2012) (Mahon, Friedlingb, \& Gordonc, 2018). (Batra, Mahajan, Seema, \& Khurana, 2020)suggested that the left clavicle can give better results for estimation of gender than right clavicle, a study conducted on a population of Punjab region in India justified this study, the study also concluded with mid shaft measurements playing an important role in age and gender estimation. (Messer \& Getz, 2020) Showed how FORDISC has been a valuable tool in forensic anthropological analysis but slight changes in determination of biological profiling can result in disrupted results and wrong interpretation of parameter of an individual. This might affect the cases and reliability of the evidence.

\section{EXPERIMENT AND RESULT}

The study is a review of literature and secondary source of information to reach a conclusion related to Clavicle as crucial biological evidence in forensic anthropological investigation.

\section{CONCLUSION}

The paper concludes the importance of clavicle as important evident bone of forensic investigation. FORDISC is an important tool in forensic anthropology investigation, but clavicle provides mixed results with population and measurements. More focus shall be put towards development of analytical method of clavicle biological profiling and investigation.

\section{REFERENCE}

[1] Auerbach, B. M. (2018). Stature Estimation. The Encyclopedia of Archaeological Sciences. , 1-4.

[2] Batra, A. S., Mahajan, A., Seema, \& Khurana, B. S. (2020). Sex Determination from Clavicle Bone for Punjab Zone. Indian Internet Journal of Forensic Medicine \& Toxicology , 1-8.

[3] Bhise, S. S., Chavan, G. S., \& Chikhalkar, B. G. (2012). Age determination from clavicle: A radiological study in Mumbai region. Journal of Indian Academy of Forensic Medicine, 7-9.

[4] Black, S. (2018). Forensic Anthropology. The International Encyclopedia of Anthropology , 1-14.

[5] Burns, K. R. (2013). Forensic Anthropology Training Manual. united staes of america: Pearson Education, Inc.
[6] Christensen, A. M., Passalacqua, N. V., \& Bartelink, E. J. (2014). Forensic Anthropology:Current Methods and Practice. San Diego,CA: Elsevier Inc.

[7] Dirkmaat, D., Garvin, H., \& Cabo, L. L. (2018). Forensic anthropology. The International Encyclopedia of Biological Anthropology. , 1-17.

[8] Klepinger, L. L. (2006). Stature Estimation. In L. L. Klepinger, Fundamentals of Forensic Anthropology, (pp. 77-88). united states: John Wiley \& Sons, Inc.

[9] Langley, N. R., \& Tersigni-Tarrant, M. A. (2017). Forensic Anthropology:A Comprehensive Introduction. Florida: CRC Press.

[10] Mahon, T., Friedlingb, L. J., \& Gordonc, G. M. (2018). Union of the medial clavicular epiphysis in a South African Black skeletal sample. Journal of Comparative Human Biology , 1-21.

[11] Messer, D. L., \& Getz, S. M. (2020). Effect of sex misclassification on the skeletal biological profile. In A. Klales, Sex Estimation of the Human Skeleton (pp. 5372). Florida: Academic Press.

[12] Moore, M. K., \& Ross, A. H. (2013). Stature Estimation. In E. A. DiGangi, \& M. K. Moore, Research Methods in Human Skeletal Biology (pp. 151-179). united states: Elsevier Inc.

[13] Raxter, M. H., \& Ruff, C. B. (2018). Full Skeleton Stature. unitedstates: Elsevier Inc. All rights reserved.

[14] Sarajlic, N., \& Klonowski, E.-E. (2012). Method of Age Estimation of Adults from Thoracic Vertebra. 19th IAFS World Meeting (p. 1). Madeira - Portugal: 19th IAFS World Meeting.

[15] Schmitt, A., Cunha, E., \& Pinheiro, J. (2006). Forensic Anthropology and Medicine:Complementary Sciences From Recovery. New Jersey: Humana Press Inc.

[16] Singh, I. (2009). TextBbook of Human Osteology. New Delhi: Jaypee Brothers Medical Publishers (P) Ltd.

[17] Szilvássy, J. (1980). Age determination on the sternal faces of the clavicula. Journal of Human Evolution , 609610.

[18] T, M., Friedling, ,. L., \& Gordon, G. M. (2018). Union of the medial clavicular epiphysis in a South African Black skeletal sample. HOMO - Journal of Comparative Human Biology , 1-20.

[19] Tersigni-Tarrant, M. A., \& Shirley, R. N. (2013). ForensicAnthropology:An Introduction. florida: CRC PressTaylor \& Francis Group.

[20] Torimitsu, S., \& Makino, Y. (2016). Anthropology: StatureEstimationfromtheSkeleton. ElsevierLtd. , 100105.

[21] Tortora, G. J., \& Derrickson, B. (2009). Principles of anatomy and physiology. hoboken, united states of america: John Wiley \& Sons, Inc. 